\title{
Reformation and transformation of charity work at the beginning of the new time
}

\author{
Igor B. Ardashkin $^{1 \mathrm{a}}$, Alexander A. Bykov ${ }^{2}$ \\ ${ }^{1}$ Tomsk Polytechnic University, 634050 Lenin Avenue, 30, Tomsk, Russia \\ ${ }^{2}$ Tomsk State University, 634050 Lenin Avenue, 36, Tomsk, Russia
}

\begin{abstract}
This article is aimed at studying the transformation of Christian charity at the beginning of the New Time and the analysis of changes ongoing in this sphere. The authors of this research start with the analysis of the situation that had been formed in the economy, culture and activity of the Roman Catholic Church in the late Middle Ages. Such a preliminary excursion into the historical domain is not coincidental. It assists understanding the reasons for the Reformation and later events. However, "in the beginning was the Word", therefore, the text analyzes the ideas of such founding fathers of Protestantism as Martin Luther, John Calvin, Huldrych Zwingli. The new ideology along with the sociocultural and socioeconomic factors promoted the formation of a radically different and more creative social system, also including the charity sphere that became more rational, practical and rough.
\end{abstract}

\section{Introduction}

The Reformation is the name for one of the largest events in the world history whose title encompasses the whole period of the New Time, from the $16^{\text {th }}$ to the first half of the $17^{\text {th }}$ centuries ("the reformation period" of 1517-1648). Though this course of events is quite often more exactly called the religious or church reformation; in reality, it had greater importance being a crucial moment both in the religious, as well as political, cultural and social history of the Western Europe [1].

In the $15^{\text {th }}$ century, and entirely probable in the $14^{\text {th }}$ century, there occurred a "latent" preparation for the reformation period. A rise in the economy, trade and culture was observed, but the main "point" of growth was the development of towns and cities. F. Brodel called towns the electric transformers: they increase strain, accelerate exchange, constantly control the lives of people. There indeed formed one of the most ancient and revolutionary of all the divisions of labor: fields, on the one hand, and the so-called urban activities, on the other [2]. In truth, all the radical changes in the world history are connected with the growth of towns and cities in one way or another: these are both the city-states of the Sumerian, the polis cities in the Ancient Greece and Italy, mere towns of medieval Italy as an economic and mental foundation for the Renaissance [3].

It was exactly in towns that innovative types of activities were born, as well as new organization forms, technologies and methods of management. The towns were places of formation for such progressive types of

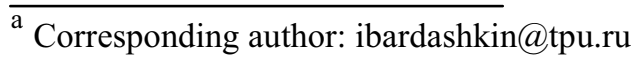

closed philanthropic institutions as poorhouses, hospitages, houses of mercy, later hospitals, etc. The city is always creative, even in the most ritual and stagnant ages. The reason for this lies in the peculiarities of the urban communication between individuals. Interaction occurs among people having various nature of their activity, education, culture and language (though there is always one language for communication available). It is in the cities where different social practices coincide. Therefore, the city of the Renaissance is a unique integrity and a special environment that is obliged to protect itself. The city people are always involved with constructing their social reality, i.e. their oikos.

Thus, the times preceding the Renaissance in the Western Europe witnessed the process of urbanization that undoubtedly influenced all the life spheres of the society, including the social one that was, above all, founded on philanthropic bases.

\section{The Subject and Methods of Research}

The authors intend to use the method of explication with the help of which they plan to specify a number of crucial notions connected with charity $[4,5]$, and the method of comparative and historical analysis with the purpose of demonstrating the transformations that emerged along with the phenomenon of charity.

\section{The Obtained Results}


Starting with the $5^{\text {th }}$ century AD (the fall of the Western Roman Empire), the church became the main subject of support for the most vulnerable society layers, and the organizer and inspirer for philanthropic activity. However, at the end of the Middle Ages, the Catholic Church was in the crisis condition, and the aims of the church and society started to grow apart. This was mentioned by B. D. Porozovskaya, a Russian historian of the second half of the $19^{\text {th }}$ century, that: "On the one hand, there was the utmost degeneration of the Roman Church, the moral decadence and ignorance of the clergy that was accompanied by the ultimate loss of its former charm in the eyes of people. On the other hand, huge success and expansion of knowledge due to the revival of sciences and arts, owing to the invention of book printing and a whole range of outstanding discoveries in the fields of geography and astronomy, were the reasons that caused dissatisfaction with the whole medieval system" [6].

The system of values and norms as well as the ethical image of the era was under change, and the departure from the principles of early Christianity was further observed. This was described by I. Heyzinga: "It was exactly the combination with the primitive pride that gave the greediness in the late Middle Ages something unmediated, ardent and outrageous, that was apparently irrevocably lost in later times. The Renaissance and Protestantism filled mercenariness with ethical content, legitimating it as a necessary condition for well-being. The stamp on it was turning more pale, while the resignation of worldly goods was being recognized as less praiseworthy and convincing. But the late Middle Ages time was only able to see an irresolvable contradiction between the virtueless greediness and generosity or voluntary poverty" [7].

At the beginning of the $16^{\text {th }}$ century, Europe entered a rather complicated and contrasting period that was to change charity as a social and cultural phenomenon. Such tendencies as strengthening secularism and nationalization in the sphere of regulation and control were developed further. However, "in the beginning was the Word".

The reformers of the church - M. Luther, J. Calvin and $\mathrm{H}$. Zwingli - were not only theorists of changes, but also their practitioners, especially the latter two.

In his work "Manual on Christian Belief', John Calvin justified the connection between religion and mercy: "It has been correctly said that differentiation is not only the main constituent part of any righteousness and virtue; it is their life-giving soul. Without the fear of God there will never be justice or mercy in the relationships between people" [8].

In the teaching of J. Calvin, moral and ethical motives are rather strong. He underlined that "the Lord forbids us to humiliate our neighbor and do them harm because He wishes the life of the neighbor to be dear to us. Therefore, He demands from us to also commit deeds of mercy owing to which this life may be kept safe" [8].

People are obliged to do good to their neighbors since charitable acts are an argument in favor of godliness, and "love that is due to our natural corruption can be directed at ourselves by ourselves and must spread outside so that we are ready to do the same amount of good to others as we do to ourselves" [8].

J. Calvin was thoroughly familiar with the works by the ancient authors, in particular, with the philosophical works by Cicero and Seneca, and, like them, he introduced some moral limitations into the sphere of charity work. Virtue and helping others when giving alms must not be motivated by vanity alone. By quoting the authority of the Gospel of John, the French Protestantism theorist wrote that "vain people, i.e. those seeking the worldly glory, or people thrust with selfcomplacence cannot be accepted by God." He declares that "the former have already received their reward in this world" (Matthew 6: 2), while "the latter are farther from the Kingdom of God than tax collectors and harlots" [9].

Another moral limitation for charity work was the absence of any hints at humiliating the one in need of help "by one's proud look or arrogant speech". The begging person may be disliked by a merciful person or may be unworthy of alms, but the "image of God" that we contemplate in this person is quite worthy to be given everything we have" [8]. This idea of embracing God's image in the face of a beggar is nothing new. John Chrysostom wrote: "You dress Christ by dressing a poor one [10]; God is hidden in poverty; a poor one offers his hand, and God receives. When sorrow happens to you, give alms at once - thanks for its happening, and you will see the joy that will overwhelm you" [10]. The main ideas and assumptions of J. Calvin's theology altogether correspond to the common Christian semantic field. This is also justified by the social and psychological assumption - put yourself in the place of a suffering beggar, penetrate deeply into the worries of the one in need of help. Charitable people were to take compassion on his/her destiny, "as if they felt its attacks themselves so that they feel the same compassion and mercy towards them as they are able to feel for themselves" [8].

An ability for empathy is the most important quality of the philanthropist and if it is absent, there is a cold and heartless following the Christian "formalities" facing us. The more so if the humiliation of the poor by some "vessels of mercy" is described by J. Calvin himself, this implies that such instances were facts in everyday life.

The other theorist and practitioner of Protestantism, $\mathrm{H}$. Zwingli, was clearly trying to return to the norms of the early Christianity, at least as he imagined them. He set himself a considerably complex goal - that of religious and moral reeducation of the yet non-Catholic society. The individuals who were part of the society were to determine their religious identity themselves and create their own system of inner control, including help to those in need.

In practice, this meant assistance in increasing the moral discipline in people, in particular, by creating marriage courts, and excommunicating for sins. Laws against excessive wastefulness, drunkenness, gambling, etc. were ordained. The last statute of 1530 was distinctive for its particular severity. The number of inns was limited, their holders were obliged not to sell wine before the office of the Mass, but to lock their facilities 
no later than $9 \mathrm{pm}$ or lend wine for more than 10 shillings [6].

The severity of actions undertaken by the new church reminds us of the order in the early Christian communities that was based on the directions of the Apostles' Decrees.

Developing a disciplinary record, responsibility and individualism of the new community members, $\mathrm{H}$. Zwingli admitted the existence of people in need of help, such as orphans, old people, the poor, the disabled, the sick, who are always there. Thus, charity work was developing but on new bases, though possibly being the forgotten old ones.

There were means for charity work, first of all, due to secularization of church possessions. Zurich hosted a whole network of philanthropic institutions. Begging and clueless almsgiving were forbidden as J. Calvin would expect: "there is no place for beggars in the city". All the city or town dwellers were obliged to work. Instead of feeding the beggars, there were reserve shops established for helping the population in need, from whence special workers distributed and even delivered comestibles to the poor and sick at door; poorhouses, inns for the poor travelers, hospitals and special plague hospitals were also founded [6].

Rationalization of charitable practices during and after the Reformation was the main feature for the development of this social and cultural phenomenon. Making charity work pragmatic is genetically connected with the base principle of Protestantism - replacing the authority of the church and papacy with the authority of the Holy Scripture texts. The realization of this principle enabled liberation of the energy and creativity of the Protestant community members and provision of more targeted help to people in need.

The Reformation influenced the charity work in Europe as a whole, including the Catholic regions. The new social, economic and political realities led to reforming the ways of helping the population. As K. Borgman and D. Smith suppose: "We know one thing for sure: within a relatively short time, the reforms advanced rapidly in a few cities at once: in 1522 - in Nuremberg, in 1523 - in Strasbourg, in 1525 - in Mons, in 1525 - in Ypres, in 1527 - in Lille. Their climax was the long-awaited decree on the imperial reform published by Charles V in 1531 . That decree covered the reforms that had been conducted in many towns and cities of the Holy Roman Empire and gave them a legislative character" [11].

Centralization, first of all, at the level of the municipal power became the main factor for developing charity work in the Western Europe.

During the $16^{\text {th }}$ century, many large cities managed to centralize their help for the poor strata of population and take control over the various philanthropic institutions that were often outdated and ineffective. The alien people and beggars were evicted from the cities, and the beggars, who were able to work, were forced to labor. Many cities created centralized foundations for almsgiving that were based on private donations and specially introduced taxes. Such cities in the Northern Europe as Ypres, Nuremberg, Paris and Lion were exemplary for 60-70 others, both Catholic and Protestant, towns and cities where similar reforms were conducted [11].

The supreme secular power in the face of the monarchs did not pay special attention to the charity work. In their decrees, the emperor Charles $\mathrm{V}$ and the king of France Francis I set general intentions for the state's interference in the social sphere of their epoch. In 1520, Francis I (1494-1547) set a task of reforming the hospitals and king's shelters. The main giver of the royal alms gave the order to place two inspectors in every parish - one of the clergymen and one of the laymen who were supposed to collaborate in supervising the course of the reforms [11]. However, this was the maximum impact of the supreme state power on the charity work, while the main role in reforming the "godly" institutions was still played by municipalities.

The experience of charity work development in England is quite interesting. After the Norman Conquest, this country, as opposed to many European countries, was governed more centrally. It had an influence on reformation of every sphere of social support of the population encouraging a serious interference of the royal power and towns. Some arrangements of Anglicanism made by XXXIX members of the Anglican teaching (1563) encouraged this activity. Part XXXVIII says that "the wealth and possessions of Christians in relation to the right and ownership were not common as Anabaptists erroneously claim; still, every person was obliged to give alms to the poor from his possessions to the best of his ability" [12].

Religious assumptions of Anglicanism were undoubtedly influencing the practical activity of the authorities. Thus, "during 1540-1550 the orderly system of shelters was created by the London authority: some shelters provided care for the sick and paralytic, one of them was intended for the acceptance of foundlings, and another one was a location for placing the idlers and persons without particular activities. In general weakening of monasteries and other medieval godly institutions encouraged the English people to consolidate their efforts in the parish charity work and try to put the system of almsgiving into order. Henry VIII (1491-1547) issued a decree in accordance with which every town was to establish a foundation for helping the poor. All the voluntary donations (obligatory taxation was out of the question) were to be handed over to the stewards of these foundations, but not to the street beggars except the cases when the latter clearly belonged to some special classes, like, for example, blind people or sailors of a wrecked ship [11].

In 1601, England passed the "Statute on the Charity Use" that reflected the common Christian traditions of both philanthropy and new social and economic reality. The preamble listed the following charity targets: helping the poor, paralytic, elder, sick and lame soldiers and sailors; schools, colleges and universities; fixing bridges, quays, havens, dams, temples, parapets and driveways; educating and materially supporting the orphans; supporting the correctional facilities; assisting in marriages of poor maidens; helping and supporting the young merchants and craftsmen, even in the case of their 
financial collapse; buying war prisoners off and paying debts for convicts [11]. However, private charity was encouraged above all.

England's system of charity work was one of the most developed in Europe, still it was far from perfection. The European towns and cities witnessed more frequent breaking the evangelical principles of helping the poor. Some towns and cities could feed poor people and then cast them out. This was a usual practice. As F. Brodel wrote, the problem was in depriving the poor of the ability to do harm. In Paris, the poor and disabled were always placed in hospitals, while the healthy population was used at hard and wearisome works, such as endless cleaning of the city's ditches and drains, what is more, they were enchained by two. In England, at the end of the Elizabeth's reign, there appeared "laws on the poor" (Poor Laws) that were in fact the laws against the poor. Gradually, it was across all the West that the number of houses for the poor and undesirable people was multiplying, where the person was sentenced to the forced labor in work houses, just as in the German "foundling hospitals" or French "forcing houses" (French maisons de force) as, for instance, the complex of half-prisons that were united by the administration of the Paris Big Hospital founded in 1656. This "great confinement" of the poor, mentally sick, delinquents or sons that were thus placed under supervision by their parents was one of the psychological aspects of the society in the $17^{\text {th }}$ century, a society prudent, but ruthless in its prudence [1].

The decadence of the traditional society was accompanied by the erosion of the base values and norms of behavior, violation of customary social connections, including those that support the most vulnerable sectors of the society. The situation of anomie started to form in the $16^{\text {th }}$ century, but still as a local phenomenon. The capitalist system was formed gradually and non-uniformly without or little involvement of the significant regions. However, in the more advanced areas the population was differentiated and the number of the poor increased. Therefore, restriction of charity work is quite a rational, though not entirely humanist reaction to the population pauperization.

F. Brodel gave a meaningful fact: "In 1656, in Dijon, the city authorities forbade their citizens to engage in private philanthropy and give a shelter to the poor. In the $16^{\text {th }}$ century, the alien poor were treated or fed before being cast out. In the $17^{\text {th }}$ century, the poor had their heads shaved. Later the poor population was exposed to whipping, and, at the end of the century, the last word of suppression was to send a destitute person to the galleys. This was an accurate account of the peculiarities of the "charitable works" in Europe" [2].

\section{Conclusion}

Thus, with the beginning of the Reformation and subsequent changes in all spheres of life, in many regions of Europe there were observable shifts in the attitude to the poor and the forms of philanthropic assistance. The "prudent" and rational approach to support, though being rough and still not targeted, became the main tendency for the development of the charity work in the $16^{\text {th }}-1^{\text {st }}$ half of the $17^{\text {th }}$ centuries. The growth of towns and cities, as well as strengthening of the centralized power, led to the secularism and nationalization of charity work, which found its reflection in establishing the legal base of the phenomenon under study.

\section{Acknowledgment}

The results presented herein were obtained with the assistance of Russian Humanitarian Science Foundation grant 15-03-14049.

\section{References}

1. F. A. Brockhaus, I.A. Efron, Encyclopedia (SaintPetersburg, 52, 1899)

2. F. Brodel, Material Civilization, Economy and Capitalism (Moscow, 1986)

3. Bykov, Proc. Soc. and Beh. Sc., 166 (2015)

4. Ardashkin, N. V. Martyushev, P. V. Bezborodov, Proc. Soc. and Beh. Sc., 166 (2015)

5. O. Loyko, S. Dryga, J. Park, M. Palianov, Proc. Soc. and Beh. Sc., 206 ( 2015 )

6. D. Porozovskaya, Huldrych Zwingli, his Life and Reformatory Activity (Saint-Petersburg, 1892)

7. Heyzinga, Autumn of the Middle Ages (Moscow, 1988)

8. J. Calvin, Manual in Christian Belief. (Moscow, 1997, Vol. 2, Book 2)

9. The Gospel of Matthew. The Holy Gospel (Moscow, 2008)

10. Creations of the Holy Father, our John Chrysostom, Archbishop of Constantinople (Saint-Petersburg, Vol. 12, Book 1, 2, 1906)

11. K. Borgman, D. Smith, Dom. Not., 4 (2006)

12. S. D. Bondar, Anglican Episcopal Church. A Note. (Saint-Petersburg, 1911) 